若手の会だより

～関東支部の活動報告と紹介〜

\section{酒井 淳}

東京農工大学大学院工学府電子情報工学専攻
はじめに

初めまして。今回は生物物理若手の会関東支部の活 動報告等を三人で執筆いたします。まずは私，関東支 部長の酒井淳と申します。東京農工大学に学籍があり ますが, 外部研究生として東京大学総合文化研究科の 柳澤研究室で研究をしている博士後期課程の三年生で す．主にゼラチンでできたミクロゲルの物性について 研究しています。ミクロゲル単体の物性はまだ明らか にされておらず，測定装置も汪とんどないのが現状で す。私は装置作りをしつつ, 物性の解明をテーマに研 究しております。

\section{生物物理若手の会関東支部の活動紹介}

生物物理若手の会関東支部の活動について紹介しま す。まず，生物物理若手の会関東支部は，生化学若い 研究者の会, 脳科学若手の会, 分子科学若手の会とと もに「四若手合同」といら形で活動しています。内容 としては，(今のところは）年に四回，各若手の会が 主催する「四若手合同セミナー」といらセミナーを 行っています。三月に開かれている「学振セミナー」 に参加したことがある人は多いのではないでしょら か.

これらのセミナーはどんなセミナーにするかスタッ フが案を出し, 講師の先生に依頼し, 日程を調整した 上で開催されています。次回は七月に生物物理若手の 会が主催してセミナーを行ら予定です。内容としては 研究発表会を予定しています。ここしばらくは行われ ていなかったのですが，様々な分野の若手研究者相手 に自分の研究を発表して交流しょう，といら企画で す. 博士課程進学を悩んでいる方，まだ学会で発表し

E-mail: a-sakai@st.go.tuat.ac.jp (酒井)

E-mail: 8645322850@edu.k.u-tokyo.ac.jp（渋谷）

E-mail: 12s3037k@chiba-u.jp（丸山）
たことないけど人前で発表してみたい方，周りに博士 課程がいなくて人と交流がほしい方等，どんな方でも 歓迎いたします。ぜひご参加を検討してみてくださ い!

また，活動としてはこのほかにも，生物物理若手の 会の夏の学校の開催の手伝いや，持ち回りの年は開 催の準備をしています。主に開催にあたっての資金集 めや会場準備，講師の先生との連絡などなど，結構大 変ですが，やりがいも多いです。他にも，生物物理学 会の年会中に若手研究者の懇親会を開いたりしていま す.このようにして，主に全国の若手研究者同士の交 流を図る・促すような活動をしています。

\section{四若手合同セミナ一の報告}

千葉大学の村田研究室に所属している丸山です。私 は, 分子モータータンパク質の動作メカニズムを明ら かにするために，主に構造生物学的な手法を用いて研 究に取り組んでいます。分子モーターの動作メカニズ ムは, 秒間 100 回転するといら時間分解能上の問題 と, ナノサイズのタンパク質中のアミノ酸側鎖の 数 の動きが機能に関連するといら空間分解能上の 問題から，詳細には描写されておりません。私は現 在これまで私が取り組んできた X 線結晶構造解析 と金沢大学の安藤教授との共同研究による高速原子間 力顕微鏡（高速 AFM）観察を組み合わせることで, 時間分解能及び空間分解能の問題を乗り越え，回転分 子モーターの一種である $\mathrm{V}_{1}$-ATPase の回転メカニズム を分子レベルで明らかにすることを目指しています。

私からは，昨年 7 月 15 日（日）に開催いたしました 四若手合同セミナーについて詳しく報告します。四若 手合同セミナーを開催するにさし当たっての一番の悩 みどころはテーマの選定です. 生物物理だけではなく, 生化学・脳科学・分子科学と幅広くの若手研究者に とって興味のあるテーマを選ぶことは，毎回一番の悩 みどころです。さて，ちょらどその前年（2017年）に クライオ電子顕微鏡法の技術開発で Jacques Dubochet, Joachim Frank, Richard Hendersonの3名がノーベル化 学賞を受賞しました. 構造生物学分野は, 最もホット な分野の 1 つであり，それに携わる私はもとより，構 造生物学が専門ではない若手の会スタッフも多くが注 目する分野でした。そこで，これを機にタンパク質構 造解析を学び, 構造生物学の最先端の研究についてご 講演いただこうと，本セミナーでは，X線結晶構造解 析とクライオ電子顕微鏡を用いた構造生物学で最前線 に立って扣られる先生として, 東京大学大学院理学 系研究科の西澤知宏先生と東京大学大学院 医学系研 
究科の吉川雅英先生にそれぞれ講演を依頼しました。 お二人とも拈忙しい中，私たち若手研究者のために拉 話することを快諾していただくことができました。

当日は東京大学駒場キャンパスの 16 号館の教室を 拈借りしました。13時からセミナーが開始され， 様々な分野で研究に励んでいる学部四年生から社会人 まで合計 27 人もの方に参加いただきました。初めに 西澤先生にX 線結晶構造解析から見た構造生物学と ご自身の研究についてご講演いただきました，次に吉 川先生にクライオ電顕から見た構造生物学とご自身の 研究についてご講演いただきました。扤二人とも用い る手法は違えども，自分の手で生命現象を明らかにす る，その道を切り開いていきたいといら熱い想いがひ しひしと伝わってきて，最先端の手法を知ることがで きたばかりではなく，私たちが研究に取り組んでいる 原動力とは何かを再確認することができました，その 後,「構造生物学と若手研究者のこれから」と題して パネルディスカッション形式にて, 会場の参加者から お二人に質問し，お二人にお答えいただく時間を設け ました. パネルディスカッションでは「今後, 蛋白質 の構造解析はどのように発展していくと考えている か」「学生・ポスドクの間にして执いて良かったこと, こらいらことをしておいたら良かったと思らことは何 か」などの質問がなされ，参加された人たちは，先生 方の答えに対してまた質問をするなど，大変盛り上 がった企画となりました．閉会後の懇親会にも，お二 人ともご参加いただき，さらに議論を深めることがで きました. 最先端の研究を進めておられる先生方の研 究, そして, 溢れ出る熱い想いも知ることができ, 大 変有意義な会になったと自負しています。

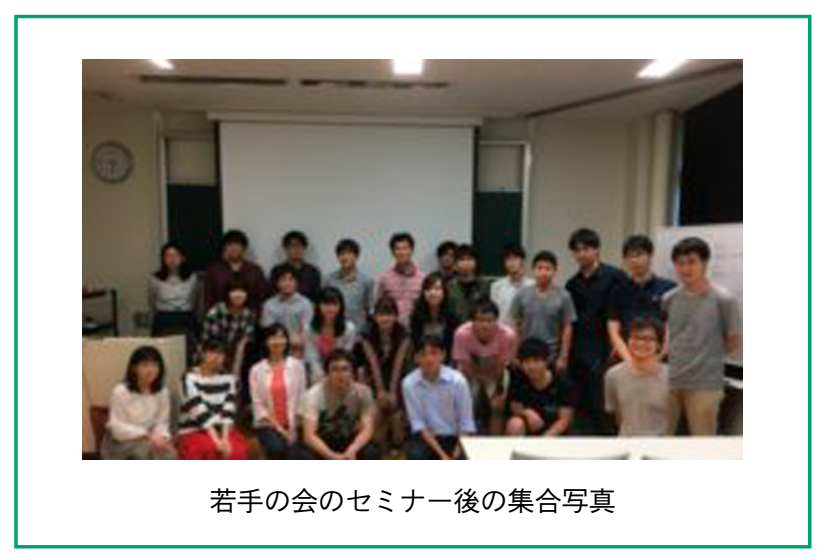

\section{若手の会参加のすすめ}

東京大学の本田研究室に所属している渋谷と申しま す．私は主に主鎖環状化タンパク質の構造安定化効果 について研究しています。主鎖環状化は環状化末端の 改変のみでタンパク質を安定化させることのできる有 用な手法ですが，構造安定化しない例も報告されてい ます。そこで，主鎖環状化タンパク質の構造安定化効 果を変性実験, 結晶構造解析, 相互作用エネルギー解 析等を使って解明することによって，主鎖環状化タン パク質の合理的設計を可能にすることを目指していま す.

私は，若手の会の活動に関わってきて思ったことを ご紹介します，若手の会は，セミナー等で出会った 方々との研究の話やとりとめのない話を通して，肩の 力を抜いて自分の研究を見つめな和すことができる, 貴重な位置にあると思います。

私は修士から外研に所属しているため, 院生と関わ る機会はほとんど若手の会を通したものでした。初め ての若手の会への参加は, 知り合いの注ぼいない夏の 学校（2016年 北海道開催）に飛び込んだことがきっ かけでした。それから約 3 年間, 想像以上に（下の学 年の方々からも）刺激を受け，情報交換をし，何度も 助けられました，今では，若手の会の方々とは，同じ 研究科の学生よりも同級生のような気持ちで接してい ます。

前述のように, 関東支部若手の会のセミナーは四若 手合同なので，毎回異なる幅広い内容と分野の方々で 構成されています。そのため, 初めて参加される方も 打ち解けやすい環境です。 セミナーの告知はメーリン グリストや若手の会のSNS 等で行っているので，た くさんの方々に参加していただけますと幸いです.

最後に，関東支部では，若手の会関東支部の運営ス タッフの募集もして扣ります。 セミナや夏の学校で 自分が注目している先生にご講演を依頼できたり，生 物物理学会としての活動（女子中高生夏の学校等）に スタッフとして参加させていただいたりすることがで きます．生物物理若手の会のスタッフ活動にご興味の ある方，生物物理若手の会関東支部のメーリスに参加 したい方は, 酒井, 丸山, 渋谷までご連絡ください. ぞらぞよろしくお願いいたします。 